\title{
Diterpene composition of oils from Arabica and Robusta coffee beans and their effects on serum lipids in man
}

\author{
RONALD P. MENSINK.* W. JANET LEBBINK, IRENE E. LOBBEZOO, \\ MARIANNE P. M. E. WEUSTEN-VAN DER WOUW, PETER L.ZOCK \& MARTIJN B. KATAN \\ From the Department of Human Nutrition, Agricultural University, Wageningen, The Netherlands
}

\begin{abstract}
Mensink RP, Lebbink WJ, Lobbezoo IE, Weusten-van der Wouw MPME, Zock PL, Katan MB (Department of Human Nutrition, Agricultural University, Wageningen, The Netherlands). Diterpene composition of oils from arabica and robusta coffee beans and their effects on serum lipids in man. J Intern Med 1995; 237: 543-50.
\end{abstract}

Objectives. The cholesterol-raising effect of boiled coffee is caused by diterpenes from coffee oil. In order to identily the diterpene responsible, we analysed the diterpene composition of oils from Arabica (Coffea arabica) and Robusta (Coffeca canephora robusta) beans and their effects on serum lipids and thyroid function. Design, Subjects, and Intervention. During the first 3-week period of a randomized, cross-over trial, 11 healthy, normolipaemic volunteers received per day either $2 \mathrm{~g}$ of colfee oil $(n=5)$ or placebo oil $(n=6)$. After a 2-week wash-out, the reverse treatments were applied for another 3 weeks. Six subjects received Arabica oll, supplying $72 \mathrm{mg}^{\text {day }}{ }^{-1}$ cafestol and $53 \mathrm{mg}$ day ${ }^{-1}$ kahweol, and five received Robusta oil, which provided $40 \mathrm{mg}$ of calestol, $19 \mathrm{mg}$ of $16-$ O-methyl-calestol, and $2 \mathrm{mg}$ of kahweol per day. Background diets were constant.
Results. The average serum cholesterol levels rose by $0.65 \mathrm{mmol} \mathrm{L}^{-1}(13 \%)$ on Arabica oil $(P<0.025$; $95 \% \mathrm{Cl}, 0.21-1.09 \mathrm{mmol} \mathrm{L}^{-1}$ ) and by $0.53 \mathrm{mmol} \mathrm{L}^{-1}$ (13\%) on Robusta oil (NS; 95\% CI -0.36$\left.1.42 \mathrm{mmol} \mathrm{L}^{-1}\right)$. The triglycerides levels rose by $0.54 \mathrm{mmol} \mathrm{L}^{-1}(71 \%)$ on Arabica $(P<0.005 ; 95 \%$ CI, $\left.0.22-0.76 \mathrm{mmol} \mathrm{L}^{-1}\right)$ and $0.49 \mathrm{mmol} \mathrm{L}^{-1}(61 \%)$ on Robusta oil $(P<0.005 ; 95 \%$ CI, $0.30-$ $\left.0.68 \mathrm{mmol} \mathrm{L}^{-1}\right)$. None of the effects on serum lipids or lipoprotein cholesterol levels was significantly different between Arabica and Robusta oil. Concentrations of serum total and free thyroxine $\left(\mathrm{T}_{4}\right)$, triiodothyronine $\left(\mathrm{T}_{3}\right)$, and thyroid-stimulating hormone (TSH) were largely unaffected.

Conclusions. Both Arabica and Robusta oil elevated serum lipid levels; therefore, cafestol must be involved and kahweol cannot be the sole cholesterol-raising diterpene. The mode of action of coffee diterpenes does not involve induction of hypothyroidism.

Keywords: blood lipids, coffee, diterpenes, experiment, humans, thyroid hormones.

\section{Introduction}

Scandinavian-style boiled coffee raises serum cholesterol levels in humans [1-4], whereas drip filtered coffee has little or no effect [5-9]. Boiled coffee contains a small amount of lipid material [10], which is removed upon filtering [] 1, 12]. Diterpenes from this coffee lipid fraction are responsible for the cholesterol-raising effect of boiled coffee $[13,14]$.

\footnotetext{
* Present address: Department ol Human Biology, Limburg Universily, PO Box 616,6200 MD Maastricht, The Netherlands.
}

The two major commercial strains of coffee are Coffea arabica (Arabica) and Coffea canephora var. robusta (Robusta) [15]. Arabica beans are the major type used in Scandinavia, whilst Robusta coffee is more popular in southern Europe. It has been suggested that coffee made from Robusta beans raises cholesterol more than does coffee from Arabica beans [9]. However, Arabica beans have a higher diterpene content than Robusta beans, mainly due to a much larger amount of kahweol [15]. On the other hand, Robusta beans are the only ones to contain 16-0-methyl-cafestol [16]. A comparison of Arabica 
and Robusta coffee lipids should help to evaluate the health effects of the two types of beans.

We therefore studied the effects of Arabica and Robusta oil on serum lipid and lipoprotein levels in a randomized, cross-over experiment. As the simultaneous rise in serum cholesterol and serum triglycerides resembles the changes seen in hypothyroidism, we also investigated the effect of coffee oil on serum levels of thyroid hormones and thyroidstimulating hormone (TSH). The effects on liver enzymes have been described previously [13].

\section{Subjects and methods}

In our previous study [10], supplementation of $1.3 \mathrm{~g}$ of lipid material from boiled coffee increased the serum total cholesterol level by $0.74 \mathrm{mmol} \mathrm{L}^{-1}$ and low-density lipoprotein (LDL) cholesterol by $0.50 \mathrm{mmol} \mathrm{L}^{-1}$. Using these estimates and their standard deviations [10], we calculated that to detect similar changes with a statistical power of $85 \%$ we would need five subjects in each coffee oil group. We therefore recruited 12 volunteers, one of whom dropped out in week 1 . The 11 remaining subjects, six women and five men, were students at Wageningen Agricultural University. They were in good health, none had glucosuria or proteinuria, and none was taking any medication known to affect serum lipids.

Table 1 shows the baseline characteristics of the subjects. The volunteers did not receive payment. The protocol and aim of the study were explained to them, and they gave their informed consent. Prior approval for the study was obtained from the human ethics committee of the department.

\section{Coffee oil}

The coffee oil was produced by Nestec Ltd. Research Centre (Vers-chez-les-Blancs, Lausanne, Switzerland) by extrusion of roasted Arabica and Robusta beans followed by filtration and centrifugation to remove solid particles. The Arabica beans came from Costa Rica and the Robusta beans from the Ivory Coast. For analysis of diterpenes and phytosterols, samples were saponified with ethanolic $\mathrm{KOH}, 2 \mathrm{~mol} \mathrm{~L}{ }^{-1}$, for $30 \mathrm{~min}$ at $100^{\circ} \mathrm{C}$, after the addition of $5-\alpha$-cholestane and betulin as internal standards. The free diterpene alcohols were extracted three times with $2 \mathrm{~mL}$ of diethylether. The solution was dried at $45^{\circ} \mathrm{C}$ with nitrogen and redissolved in $0.5 \mathrm{~mL}$ pyridine (Merck,
Darmstadt, Germany; no. 7463). Then $150 \mu \mathrm{L}$ of a $2: 1$ (vol/vol) mixture of hexamethyldisilazane (Pierce, Rockford, IL, USA; no. 84770) and trichloromethylsilane (Pierce; no, 88530) was added. After $30 \mathrm{~min}$ of trimethylsilyation at ambient temperature, excess pyridine was removed under a stream of nitrogen and $1.0 \mathrm{~mL}$ of high-performance, liquid chromatography (HPLC) grade hexane (Rathburn Chemicals Ltd, Walkerburn, UK) was added. Then $1.0 \mu \mathrm{L}$ of the sample was injected into a Hewlett Packard 5890 series II gas chromatograph (Avondale, PA, USA) and separated on a $25 \mathrm{~m} \times 0.22 \mathrm{~mm}$ fused silica $\mathrm{CP}$ Sil $5 \mathrm{CB}$ column (Chrompack, Middelburg, The Netherlands), using nitrogen as a carrier gas at a pressure of $100 \mathrm{kPa}$. The initial oven temperature was $70^{\circ} \mathrm{C}$ followed by a rise to $200^{\circ} \mathrm{C}$ at a rate of $40^{\circ} \mathrm{C} \mathrm{min}^{-1}$. After $10 \mathrm{~min}$, the temperature was raised to $235^{\circ} \mathrm{C}$ at a rate of $6^{\circ} \mathrm{C} \mathrm{min}{ }^{-1}$, and then to $285^{\circ} \mathrm{C}$ at a rate of $30^{\circ} \mathrm{C} \mathrm{min}{ }^{-1}$. The authenticity and purity of peaks was verified by mass spectrometry on a Finnegan (San Jose, CA, USA) model 8430 mass spectrometer coupled to a Hewlett-Packard (Avondale, PA, USA) 5890 gas chromatograph and using pure compounds as standards. The coefficient of variation for the control coffee oil was $2.0 \%$ within and $2.4 \%$ between runs for cafestol, and $2.9 \%$ and $2.5 \%$, respectively, for kahweol.

\section{Design}

Each volunteer received daily six capsules containing $0.33 \mathrm{~g}$ of coffee or placebo oil, for a total of $2 \mathrm{~g}$ of oil per day. Two grams of oil correspond to $1-2 \mathrm{~L}$ of boiled coffee per day, a consumption level which is not unusual in Finland and Norway [4]. In order to maximize diterpene absorption, subjects were instructed to take three capsules with their breakfast and three capsules with their evening meal. The placebo oil was a 1:1 mixture of palm and sunflower oil that mimicked the fatty acid composition of the coffee oil. During the first 3 weeks, five subjects received capsules with coffee oil and six received placebos. Weeks 4 and 5 consisted of a wash-out period during which placebo oil was given to all 11 subjects. During the final 3 weeks, subjects who had received placebo during the first 3 weeks received coffee oil and the others received placebo.

Each Tuesday, 18 capsules were handed out to each volunteer, and each Friday, 24 capsules. 
Table 1 Baseline characteristics of the subjects on the two types of coffee oil ${ }^{*}$

\begin{tabular}{lll}
\hline & Arabica oil $(n=6)$ & Robusta oil $(n=5)$ \\
\hline Males/lemales & $3 / 3$ & $2 / 3$ \\
Age (years) & $22 \pm 1(20$ to 23$)$ & $24 \pm 2(22$ to 26$)$ \\
Total cholesterol $\left(\mathrm{mmol} \mathrm{L}^{-1}\right)$ & $5.15 \pm 0.42(4.77$ to 5.80$)$ & $4.58 \pm 0.26(4.20$ to 4.90$)$ \\
LDL cholesterol $\left(\mathrm{mmol} \mathrm{L}^{-1}\right)$ & $3.20 \pm 0.43(2.57$ to 3.78$)$ & $2.93 \pm 0.26(2.73$ to 3.36$)$ \\
HDL cholesterol $\left(\mathrm{mmol} \mathrm{L}^{-1}\right)$ & $1.55 \pm 0.42(1.00$ to 2.16$)$ & $1.16 \pm 0.24(0.88$ to 1.52$)$ \\
Triglycerides $\left(\mathrm{mmol} \mathrm{L}^{-1}\right)$ & $0.88 \pm 0.14(0.73$ to 1.11$)$ & $1.08 \pm 0.29(0.67$ to 1.43$)$ \\
Body-mass index $\left(\mathrm{kg}^{2} \mathrm{~m}^{2}\right)$ & $22.9 \pm 2.2(20.3$ to 26.8$)$ & $22.1 \pm 2.7(20.1$ to 26.7$)$ \\
\hline
\end{tabular}

* Values are means $\pm \mathrm{so}$ (ranges).

Subjects took three capsules in the morning and three in the evening. Neither the investigators who were in contact with the volunteers, nor the technicians, knew the regimens of the subjects. Although the study was planned to be double-blind, the subjects were able to recognize the coffee oil capsules by their strong taste upon regurgitation. However, it is unlikely that this affected the outcome of the trial. Subjects were urged to maintain their usual pattern of activity and diet, and to abstain from non-filtered types of coffee. They recorded in diaries any signs of illness, medications used, their coffee consumption, and any deviations from the protocol. One subject reported that he had missed a total of three coffee oil and nine placebo oil capsules over the duration of the trial; two other subjects had missed six coffee oil capsules. Inspection of the diaries did not reveal any other significant transgressions.

Nutrient intake was assessed by 24-h recall [17], always on the same day of the week, before and 6 weeks after the start of the study (Table 2).

The intake of energy or nutrients did not significantly differ between the treatments and there were no considerable changes in diet during the trial. At the most, there was a tendency in the Robusta group towards decreased total fat intake. However, the Robusta oil and placebo oil were supplied in random order, and dietary changes, if any, thus could not have systematically biased the results. The coffee oil provided $0.3 \%$ of daily energy from saturated and another $0.3 \%$ from polyunsaturated fatty acids. Keys' equation [18] predicts that neither coffee oil nor placebo oil would affect the serum cholesterol level. Body weight changed by $1.0 \pm 1.5 \mathrm{~kg}$ (mean $\pm \mathrm{sD}$ ) from week 1 to week 3 and by $-0.7 \pm 0.9 \mathrm{~kg}$ from week 5 to week 8 . Weight changes were not associated with any specific treatment.

\section{Blood sampling and analysis}

Blood was sampled after an overnight fast on day -7 (pre-experiment), days 11, 18 and 21 (period $\mathrm{r}$ ), day 35 (end of wash-out period), days 53 and 56 (end of period II), and 6 weeks after the study had ended, Serum was obtained by low-speed centrifugation. The samples obtained after the first 11 days of coffee oil supplementation were immediately analysed for total cholesterol, and the results were reviewed by an investigator (MBK) who was never in contact with the subjects. The protocol required the coffee oil supplementation to be terminated if the mean rise in cholesterol after 11 days exceeded $1 \mathrm{mmol} \mathrm{L}^{-1}$ which it did not. All other samples were stored at $-80^{\circ} \mathrm{C}$ and analysed for total and high-density lipoprotein (HDL) cholesterol and triglyceride levels after the trial had ended $[19,20]$.

The lipid laboratory was standardized by the Netherlands Foundation for Quality Control of Hospital Iaboratories. The coefficient of variation of control sera within one run was $1 \%$ for total cholesterol, and $2 \%$ for HDL cholesterol and triglycerides. Additional analyses of serum pools provided by the US Centers for Disease Control (Atlanta, $\mathrm{GA}$ ) resulted in a bias with regard to the target values of $-0.7 \%$ for total cholesterol and $-1.3 \%$ for triglycerides. The mean bias with regard to target values of four serum pools obtained from the Solomon Park Research Laboratories (Kirkland, WA) was $-2 \%$ for HDL cholesterol. LDL cholesterol was calculated [21].

Sera obtained on days $18,21,53$ and 56 were also analysed for total thyroxine $\left(\mathrm{T}_{4}\right)$ using the kit (SPACrET.FT ${ }_{4}$ ) supplied by Byk-Sangtec Diagnostica (Dietzenbach, Germany), free thyroxine and triiodothyronine $\left(\mathrm{T}_{3}\right)$ using radioimmunoassay (RIA) kits 
Table 2 Mean energy and nutrient intake $( \pm 8 D)$ in the week before and in the 6 th week of the trial

\begin{tabular}{|c|c|c|c|c|}
\hline & \multicolumn{2}{|c|}{ Arabica group } & \multicolumn{2}{|c|}{ Robusta group } \\
\hline & Week -1 & Week 6 & Week -1 & Week 6 \\
\hline Energy (M) day ${ }^{-1}$ ) & $13 \pm 4$ & $13 \pm 2$ & $12 \pm 1$ & $11 \pm 2$ \\
\hline T'otal fat [energy (\%)] & $41 \pm 5$ & $41 \pm 7$ & $39 \pm 4$ & $36 \pm 7$ \\
\hline Saturated & $17 \pm 4$ & $19 \pm 4$ & $16 \pm 5$ & $15 \pm 3$ \\
\hline Monounsaturated & $14 \pm 2$ & $13 \pm 2$ & $14 \pm 1$ & $13 \pm 4$ \\
\hline Polyunsaturated & $7 \pm 3$ & $6 \pm 2$ & $6 \pm 2$ & $7 \pm 2$ \\
\hline Carbohydrates [energy (\%)] & $44 \pm 3$ & $43 \pm 7$ & $47 \pm 7$ & $47 \pm 8$ \\
\hline Protein [energy (\%)] & $13 \pm 2$ & $16 \pm 7$ & $15 \pm 4$ & $16 \pm 5$ \\
\hline Alcohol [energy (\%)] & $3 \pm 4$ & $2 \pm 3$ & 0 & $1 \pm 3$ \\
\hline Cholesterol (mg MJ ${ }^{-1}$ ) & $19 \pm 5$ & $28 \pm 7$ & $25 \pm 9$ & $22 \pm 7$ \\
\hline
\end{tabular}

Energy and nutrient intake was assessed by 24-h recall.

from Autopak ${ }^{\natural}$ (ICN Micromedic Systems Inc., PA, USA), and for TSH using the Delfia'NTSH kit from Pharmacia International (Uppsala, Sweden). All samples of one subject obtained during the study were analysed in the same run. Sera obtained before and after the study were analysed in separate runs.

\section{Statistical analyses}

The outcome variables consisted of the changes in serum lipid and lipoprotein levels between the end of period I (means of days 18 and 21) and period II (means of days 53 and 56). Carry-over and period effects were absent for all variables [22]. The effects of the two treatments were therefore examined using a two-sided, paired, Student's $t$ test [23]. Differences in responses to the two different types of coffee oil and differences between the sexes were examined using a two-sided, unpaired, Student's t-test.

\section{Results}

Table 3 shows the diterpene content of the oils. The total amount of diterpenes in Arabica oil was about twice that in Robusta oil. The kahweol content of Arabica oil was much higher than that of Robusta oil, whereas Robusta oil contained a significant amount of 16-0-methyl-cafestol, a substance which was not found in the Arabica oil. Both oils contained traces of kahweolene and cafestolene, which arise during roasting by loss of the $16-\mathrm{OH}$ function under formation of a double bond.

Figure 1 shows that cholesterol levels were elevated in all six subjects on Arabica oil and in four of the five subjects on Robusta oil. None of the responses in lipid and lipoprotein levels was significantly different between the Arabica and the Robusta oil groups. All effects were observed to a similar extent in men and women, and were independent of treatment order. The mean rise in cholesterol of $0.65 \mathrm{mmol} \mathrm{L}^{-1}$ (1.3\%) on Arabica oil was statistically different from zero $(P<0.025 ; 95 \% \mathrm{CI}, 0.21-$ $\left.1.09 \mathrm{mmol} \mathrm{L}^{-1}\right)$, but the increase of $0.53(13 \%)$ on Robusta oil failed to reach conventional significance limits (95\% CI, $-0.36-1.42 \mathrm{mmol} \mathrm{L}^{-1}$ ) (Table 4). The changes on Robusta oil varied more than on Arabica oil, and two subjects showed increases of

'Table 3 Diterpene and phytosterol content of oil supplements, and daily intakes during the trial

\begin{tabular}{|c|c|c|c|c|}
\hline & \multicolumn{2}{|l|}{ Arabica oil } & \multicolumn{2}{|l|}{ Robusta oll } \\
\hline & $\mathrm{g} 100 \mathrm{~g}^{-1}$ & mg day ${ }^{-1}$ & 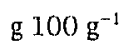 & $\operatorname{mg}$ day $^{-1}$ \\
\hline Calestol & 3.578 & 71.7 & 1.977 & 39.5 \\
\hline Kähweol & 2.643 & 52.9 & 0.120 & 2.4 \\
\hline ]6-0-methyl-calestol & 0 & 0 & 0.971 & 19.4 \\
\hline Cafestolene & 0.200 & 4.0 & 0.220 & 4.4 \\
\hline Kalhweolene & 0.117 & 2.3 & 0.007 & 0.1 \\
\hline Total diterpenes & 6.538 & 130.8 & 3.295 & 65.9 \\
\hline Phytosterols & 0.599 & 12.0 & 0.842 & 16.8 \\
\hline
\end{tabular}

\footnotetext{
* Subjects consumed $2 \mathrm{~g}$ of colfee oil per day.
} 
Fig. 1 Individual changes in serum total cholesterol and in serum triglyceride levels ( $m$ mol L ${ }^{-1}$ ) from the end of the placebo pertod to the end of the coflee oil period, Bars denote means.

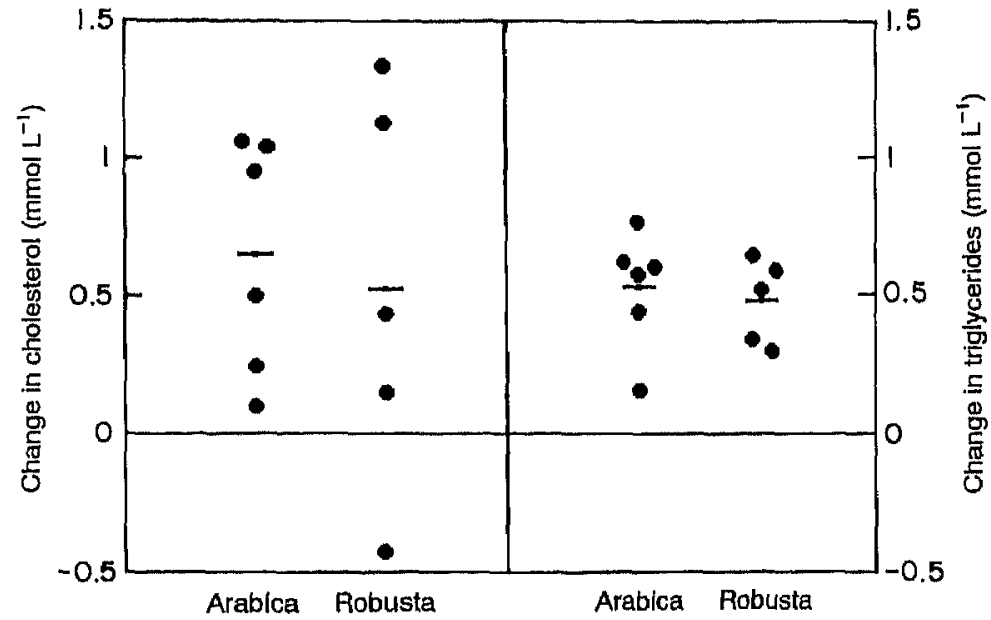

Table 4 Serum total, Jow-density lipoprotein (LDL), and highdensity lipoprotein (HDL) cholesterol and triglyceride concentrations (mmol $\mathrm{L}^{-1}$ ) after 3 weeks' supplementation with $2 \mathrm{~g} \mathrm{day}^{-1}$ of placebo oil or coffec oil from Arabica or Robusta beans* $^{*}$

\begin{tabular}{lcc}
\hline & Arabica group & Robustn group \\
\hline Total cholesterol & & \\
Placebo oil & $5.34 \pm 0.68$ & $4.46 \pm 0.42$ \\
Coffec oil & $5.99 \pm 0.59$ & $4.99 \pm 0.59$ \\
Change & $0.65 \pm 0.42 \dagger$ & $0.53 \pm 0.72$ \\
LJL cholesterol & & \\
Placebo oll & $3.37 \pm 0.55$ & $2.94 \pm 0.27$ \\
Coffee oil & $3.82 \pm 0.56$ & $3.22 \pm 0.45$ \\
Change & $0.46 \pm 0.40 \dagger$ & $0.29 \pm 0.59$ \\
HDL cholesterol & & \\
Placebo oil & $1.55 \pm 0.37$ & $1.14 \pm 0.41$ \\
Coffee oil & $1.50 \pm 0.34$ & $1.16 \pm 0.32$ \\
Change & $-0.05 \pm 0.14$ & $0.02 \pm 0.18$ \\
Triglycerides & & \\
Placebo oil & $0.93 \pm 0.48$ & $0.83 \pm 0.28$ \\
Coffec oil & $1.47 \pm 0.46$ & $1.32 \pm 0.36$ \\
Change & $0.54 \pm 0.21 \neq$ & $0.49 \pm 0.15 \ddagger$ \\
\hline
\end{tabular}

* Values are means \pm sI), Subjects recelved colfee oll and placebo oil in random order, each for 3 weeks, with a wash-out period of 2 weeks in between.

$†$ Significantly different from zero, $P<0.05$; significantly different from zero, $P<0.01$.

more than $1 \mathrm{mmol} \mathrm{L}^{-1}$ (Fig. 1). LDL cholesterol was elevated in five of the six subjects on Arabica oil and in four of the five subjects on Robusta oil. Serum triglycerides rose significantly on both oils: the mean increase was $0.54 \mathrm{mmol} \mathrm{L}^{-1}$ (71\%) on Arabica and $0.49 \mathrm{mmol} \mathrm{L}^{-1}(61 \%)$ on Robusta oil (Table 4). Changes in HDL cholesterol were slight and not significant. Six weeks after completion of the trial,
Table 5 Serum total and free thyroxine $\left(\mathrm{T}_{A}\right)$, trilodothyronine $\left(\mathrm{T}_{3}{ }_{3}\right)$, and thyroid-stimulating hormone (TSH) after 3 weeks' supplementation with $2 \mathrm{~g} \mathrm{day}^{-1}$ of placebo oil or coffee oil from Arabica or: Robusta beans*

\begin{tabular}{|c|c|c|}
\hline & Arabica group & Robusta group \\
\hline \multicolumn{3}{|c|}{ Total $T_{4}\left(\right.$ mmol $\left.L^{-1}\right)$} \\
\hline Placebo oil & $103 \pm 26$ & $95 \pm 9$ \\
\hline Colfee ofl & $105 \pm 26$ & $91 \pm 13$ \\
\hline Change & $2 \pm 9$ & $-3 \pm 8$ \\
\hline \multicolumn{3}{|c|}{ Free $T_{4}\left(m n o l ~ L^{-1}\right)$} \\
\hline Placebo oll & $1.1 .3 \pm 0.8$ & $11.4 \pm 0.8$ \\
\hline Colfee oll & $11.7 \pm 1.8$ & $11.2 \pm 0.9$ \\
\hline Change & $0.3 \pm 1.4$ & $-0.2 \pm 0.7$ \\
\hline \multicolumn{3}{|c|}{ Total $\mathrm{T}_{3}$ (nmol L-1) } \\
\hline Placebo oll & $2.8 \pm 0.2$ & $2.7 \pm 0.5$ \\
\hline Colfee oll & $2.9 \pm 0.4$ & $2.7 \pm 0.1$ \\
\hline Change & $0.1 \pm 0.5$ & $0.0 \pm 0.6$ \\
\hline \multicolumn{3}{|c|}{$\operatorname{TSH}\left(m U L_{i}^{-1}\right)$} \\
\hline Placebo oil & $1.7 \pm 0.9$ & $1.5 \pm 1.1$ \\
\hline Coffee oll & $1.9 \pm 1.2$ & $1.8 \pm 1.0$ \\
\hline Change & $0.2 \pm 0.3$ & $0.3 \pm 0.8$ \\
\hline
\end{tabular}

* Values are means \pm sis. Subjects recelved coflee oll and placebo oil th random order, each for 3 weeks, with a wash-out period of 2 weeks in between. No significant changes were observed.

serum lipids had returned to baseline levels (data not shown).

The changes in serum lipids induced by boiled coffee or coffee oil resemble those seen in hypothyroidism. However, Table 5 shows that thyroid function was not affected by supplementation of either Arabica or Robusta coffee oil. The increase in TSH levels seen on coffee oil was statistically insignificant and far below what is seen in hypo- 
thyroidism. No changes were observed in serum levels of total and free $\mathrm{T}_{4}$ and of $\mathrm{T}_{3}$.

\section{Discussion}

The intake of a mixture of cafestol palmitate and kahweol palmitate, the most abundant constituents of the unsaponitiable coffee lipid fraction [15]. elevated serum cholesterol and triglyceride levels, whereas coffee oil stripped of cafestol and kahweol had no effect [13]. Also, the free diterpenes isolated from regular ground commercial coffee were recently shown to have a powerful lipidaemic effect [14]. Robusta oil contains cafestol and 16-O-methylcafestol but only traces of kahweol, whilst Arabica oil contains significant amounts of both cafestol and kahweol but no 16-0-methyl-cafestol [15] (Table 3). We did not detect a significant difference between the effects of Robusta and Arabica oil on serum cholesterol and triglyceride levels. Serum triglyceride levels were significantly elevated on Robusta as well as on Arabica oil. Therefore, it is improbable that the effects of coffee oil on blood lipids are exclusively due to kahweol, which occurs in Arabica but not in Robusta, and that cafestol is inactive. Thus, cafestol is at least partly responsible for increasing lipid levels. It is possible that kahweol is not involved at all and that 16-0-methyl-cafestol plays a role: the increases in serum lipids on Arabica and Robusta oil were proportional to the intake of cafestol plus 16-0methyl-cafestol.

In order to enhance intestinal absorption of diterpenes, subjects were instructed to ingest the coffee oil with their breakfast and evening meals. The precise mechanisms of diterpene absorption are as yet unknown, but it is conceivable that diterpene alcohols are hydrolysed by intestinal lipases, absorbed into mucosal cells together with other fat soluble dietary substances, and subsequently incorporated in chylomicrons and secreted into lymph.

Our findings do not support the suggestion of Superko et al. [9] that Robusta coffee is more hypercholesterolaemic than Arabica. If the lipid material from Robusta is markedly more cholesterolraising than that from Arabica beans, we would have picked this up even with our small sample size, as we provided a $100 \%$ pure oil from Robusta or Arabica beans. In addition,' paper filters of the type used by the subjects in the study of Superko et al. largely eliminate the lipid material and the choles- terol-raising factor from boiled coffee [11]. Thus, it is improbable that the diterpenes present in coffee oil are responsible for the cholesterol-raising effect of decaffeinated coffee observed by Superko et al.

\section{Is thyroid function involved?}

Patients with subclinical or overt hypothyroidism have elevated levels of serum LDL cholesterol and triglycerides, but not of HDL cholesterol [24, 25]. This is similar to the changes induced by coffee lipids. Correction of thyroid function with drug therapy decreases levels of LDL cholesterol and triglycerides within 3 weeks [26]. We found no changes in the levels of total and free thyroxine and of triiodothyronine (Table 5). Changes in TSH, although in the expected direction, fell far short of what is seen in the hyperlipidaemia associated with hypothyroidism [27]. Thus, the coffee diterpenes do not appear to cause a major depression of thyroid function. The Arabica and Robusta oils tested here increase alanine aminotransferase and decrease $\gamma$-glutamyltransferase [13]. This suggests that the liver is the target organ for the diterpene-mediated influence on cholesterol homeostasis, but the precise mechanism by which consumption of boiled coffee affects serum cholesterol and triglyceride levels remains unclear.

In conclusion, oil from both Arabica and Robusta beans increased serum lipid levels in humans. This underlines the importance of cafestol plus, possibly, 16-0-methyl-cafestol, and makes it unlikely that kahweol is the single, cholesterol-raising diterpene in coffee lipids. The effect of boiled coffee on blood lipids does not seem to be mediated by thyroid hormones.

\section{Acknowledgements}

This study was supported by the Netherlands Heart Foundation through grant no. 900-562-091 of the Netherlands Organization for Scientific Research NWO.

\section{References}

1 Thelle DS, Arnesen E, Forde OH. The Tromso Heart Study. Does coffee raise serum cholesterol? $N$ Engl J Med 1983; 308: $1454-7$.

2 Porde OH. Knutsen SF, Arnesen E, Thelle DS. The Tromso heart study: coffee consumption and serum lipid concentrations in men with hypercholesterolaemia: a randomised intervention study. Br Med J 1985; 290: 893-5. 
3 Aro A. 'I'uomilehto J, Kostiainen E, Uusitalo U, Pietinen P. Boiled collee increases serum low density lipoprotein concentration. Metubolism 1987; 36: 1027-30.

4 Stensvold I. 'T'verdal A. Foss OP. The effect of coffee on blood lipids and blood pressure. Results from a Norwegian crosssectional study, men and women, 4()-42 years. J Clin Epidemiol 1989: $42: 877-84$.

5 Bonar K. Arnesen E, Thelle IS, Forde OH. Coffee and cholesterol: Is it all in the brewing? The Tromso study. Br Med 11988: 297: 1103-4.

6 Bak $A \Lambda A$, (irobbee DE. The effect on serum cholesterol levels of coflee brewed by filtering or boiling, $N$ Engl / Med 1989; $321: 1432-7$.

7 Rosmarin I'C, $A$ pplegate WB, Somes GW. Coffee consumption and serum liphds: a randomized, crossover clinical trial. $A m$ J Mel 1990); 88: 349-56.

8 van Dusseldorp $M$. Katan MB, Demacker PNM. Effect of decalfeinated versus regular coffee on serum lipoproteins. A 12-week double-blind trial, Am / Lpidemiol 1990: 132: 33-40.

9 Superko JIR, Bortz W Jr, Williams PT, Albers JJ, Wood PD. Caffehnated and deculfelnated coffee effects on plasma lipoprotein cholesterol, apolipoprotelns, and lipase activity: a controlled, rundomized trial. Am / Clin Nutr 1991; 54: 599.605.

10 Zock PI, Katan MB, Merkus MP, van Dusseldorp M, Harryvan 11. Siflect of a lipld-rich liraction from bolled coffee on serum cholesterol. Litucut 1990; 335: 1235-7.

1 I van Dusseldorp M, Kalan MB, van Vllet T, Demacker PNM, Stalenlocel AHI. Cholesterol-raising lactor from boiled coffee dow not pass a paper filter. Arteriosclerosis 1991; 11: 586-93.

12 Alwla I. Jauhlalnen M, Aro A. The hypercholesterolaemic linctor in bolled coflee is retained by a paper filter. J Intern Med $1991: 230: 293-7$.

13 Weusten-van der Wouw MP'ML, Katan MB, Vlani R, Huggett, $A C$, I.jardon $R$, Lund-Larson $P^{\prime} G$ et al. Kidentity of the cholestcrol-ralsing factor from bolled coffee and its eflects on liver functlon enzymes. J Lipid Res 1994: 35: 721-33.

14. Heckers $H$, (iobel U, Kleppel U. Find of the colfee mystery: diterpene alcohols ralse serum low-density lipoprotein cholesterol und trlglyceride levels. I Intern Med 1994; 235: 192-3.

15 Debry (3. Coffere and Health. London: John Libbey \& Company L.te. 1994.

1.6 Speer K. Monteg A. 16-(0)-methylcalestol - ein neues Diterpen
Im Kaffee. Frste ergebnisse: gehalte in Roh- und Röstkaffees. Deutsche Lebensmittel-Rundschau 1989; 85: 381-4.

17 Cameron ME, van Staveren WA, eds. Marual on Methodology for Food Consumption Studies. New York: Oxford University Press, 1988.

18 Keys A, Anderson JT, Grande F. Serum cholesterol response to changes in the diet. IV. Particular saturated fatty acids in the diet. Metabolism 1965; 14: 776-87.

19 Warnick GR, Benderson J, Albers JJ. Dextran sulfate- $\mathrm{Mg}^{2+}$ precipitation procedure for quantitation of high-densitylipoprotein cholesterol. Clin Chem 1982; 28: 1379-88.

20 Sullivan DR, Kruijswijk Z, West CE, Kohlmeier M, Katan MB. Determination of serum triglycerides by an accurate enzymatic method not affected by free glycerol. Clin Chem 1985: 31 : 1227-8.

21 Friedewald WT, Levy RI, Frederickson DS. Estimation of the concentration of low-density lipoprotein cholesterol in plasma. without use of preparative ultracentrifuge. Clin Chem 1972 18: 499-502.

22 Jones B. Kenward MG. Design and Analysis of Cross-over Trials. London: Chapman \& Hall, 1989. (Monographs on Statistics and Applied Probability, Vol. 34.)

23 Snedecor GW. Cochran WG. Statistical Methods, 7th edn. Ames, Iowa: The Iowa State University Press, 1980.

24 Althaus BU, Staub J-J, Ryff-De Lèche A, Oberhänsli A, Stähelin HB. LDL/HDL changes in subclinical hypothyroidism: possible risk factors for coronary heart disease. Clin Endocrinol 1988; 28: 157-63.

25 Tulloch BR, Lewis B, Russel Fraser T. Triglyceride metabolism in thyroid disease. Lancet 1973; ii: 391-4.

26 Kuusi T, Taskinen MR, Nikkilä EA. Lipoproteins, lipolytic enzymes, and hormonal status in hypothyroid women at different levels of substitution. / Clin Endocrinol Metab 1988; 66: $51-6$.

27 Staub JJ, Althaus U, Engler H, Ryff AS, Trabucco P. Marquardt $\mathrm{K}$ et al. Spectrum of subclinical and overt hypothyroidism: effect on thyrotropin, prolactin, and thyroid reserve, and metabolic impact on peripheral target tissues. Am J Med 1992; 92: 631-42.

Received 19 August 1994: accepted 21 November 1994.

Correspondence: Professor Dr Martijn B. Katan, Department of Human Nutrition, Agricultural University, Bomenweg 2, 6703 HD Wageningen, The Netherlands. 